\title{
$\frac{546}{2-19}-85$ os $(1)$
}

SANDIA REPORT SAND84-2171 • Unlimited Release $\bullet$ UC $-66 \mathrm{c}$

Printed January 1985

SAND $--84-2171$

\section{Selection of Promising Sites \\ for Magma Energy Experiments}

DE85 006832

Charles C. Carson

\begin{abstract}
Prepared by
Sandia National Laboratories

Albuquerque, New Mexico 87185 and Livermore, California 94550

for the United States Department of Energy
\end{abstract}

under Contract DE-ACO4-76DP00789

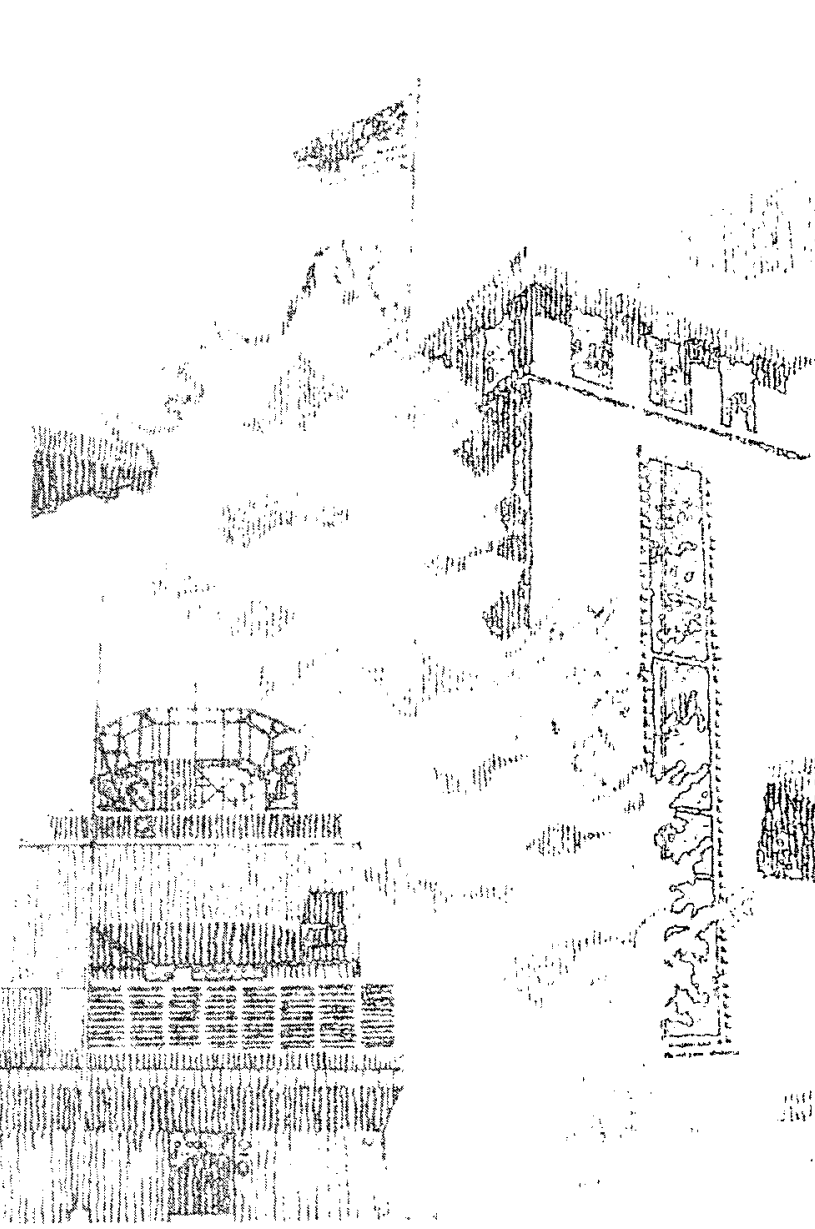




\section{DISCLAIMER}

This report was prepared as an account of work sponsored by an agency of the United States Government. Neither the United States Government nor any agency Thereof, nor any of their employees, makes any warranty, express or implied, or assumes any legal liability or responsibility for the accuracy, completeness, or usefulness of any information, apparatus, product, or process disclosed, or represents that its use would not infringe privately owned rights. Reference herein to any specific commercial product, process, or service by trade name, trademark, manufacturer, or otherwise does not necessarily constitute or imply its endorsement, recommendation, or favoring by the United States Government or any agency thereof. The views and opinions of authors expressed herein do not necessarily state or reflect those of the United States Government or any agency thereof. 


\section{DISCLAIMER}

Portions of this document may be illegible in electronic image products. Images are produced from the best available original document. 
Issued by Sandia National Laboratories, operated for the United States Department of Energy by Sandia Corporation.

NOTICE: This report was prepared as an account of work sponsored by an agency of the United States Government. Neither the United States Government nor any agency thereof, nor any of their employees, nor any of their contractors, subcontractors, or their employees, makes any warranty, express or implied, or assumes any legal liability or responsibility for the accuracy, completeness, or usefulness of any information, apparatus, product, or process disclosed, or represents that its use would not infringe privately owned rights. Reference herein to any specific commercial product, process, or service by trade name, trademark, manufacturer, or otherwise, process, or service by trade name, trademark, manufacturer, or otherwise, does not necessarily constitute or imply its endorsement, recommendation,
or favoring by the United States Government, any agency thereof or any of their contractors or subcontractors. The views and opinions expressed herein do not necessarily state or reflect those of the United States Government, any agency thereof or any of their contractors or subcontractors.

Printed in the United States of America Available from

National Technical Information Service

U.S. Department of Commerce

5285 Port Royal Road

Springfield, VA 22161

NTIS price codes

Printed copy: A02

Microfiche copy: A01 
SAND8 4- 2171

SELECTION OF PROMISING SITES FOR
MAGMA ENERGY EXPER IMENTS

Charles C. Carson

Abstract

The Long Valley and Coso Hot springs areas of California have been identified as the most promising sites for conducting a magma energy extraction experiment. These two locations were selected from among the potential sites on the basis of several factors that are critical to the success of the proposed long-term energy extraction experiment. These factors include the likelihood of the existence of shallow magma targets as well as several other drilling, energy extraction and programmatic considerations. As the magma energy extraction program continues. these sites will be analyzed in detail so that one can be selected as the site for the planned magma experiment.

\section{DISCLAIMER}

This report was prepared as an account of work sponsored by an agency of the United States Government. Neither the United States Government nor any agency thereof, nor any of their employees, makes any warranty, express or implied, or assumes any legal liability or responsibility for the accuracy, completeness, or usefulness of any information, apparatus, product, or process disclosed, or represents that its use would not infringe privately owned rights. Reference herein to any specific commercial product, process, or service by trade name, trademark, manufacturer, or otherwise does not necessarily constitute or imply its endorsement, recommendation, or favoring by the United States Government or any agency thereof. The views and opinions of authors expressed herein do not necessarily state or reflect those of the United States Government or any agency thereof. 
Selection of Promising sites for

Magma Energy Experiments

\section{Table of Contents}

$\begin{array}{ll}\text { I. Executive Summary } & 1\end{array}$

II . Introduction $\quad 2$

II . Selection Criteria and Procedures 3

IV. Potential Magma Experiment Sites 6

$\begin{array}{llr}\text { V. Results } & 8\end{array}$

$\begin{array}{ll}\text { References } & 11\end{array}$

Appendix. Discussion of Important Characteristics of 12 Individual sites 
I. Executive Summary

A program to investigate the engineering feasibility of extracting energy from shallow magma bodies was begun by the Geothermal and Hydropower Technologies Division of the U.S. Department of Energy in fiscal year 1984. This program, managed by sandia National Laboratories. has a long range goal of locating, drilling into and extracting energy from a shallow magma body in order to evaluate the engineering problems associated with tapping such bodies for energy and to provide a technology base for economic evaluation. Although the period anticipated for accomplishing this is roughly seven years, it is necessary to begin early in the program developing the technology pieces that will be required to achieve this goal. In order to do this most efficiently, it is essential to identify the best site for the magma energy extraction experiment as early as possible. In fiscal year 1984 the two best sites were identified, and they will be narrowed to a single site using investigations carried out in 1985 and 1986.

Several criteria are used to evaluate potential sites. The primary ones are: I) strong evidence locating a sizeable shallow magma body 2) the ability to reach the magma body by drilling 3 ) the ability to conduct a long term energy extraction experiment. The sites that satisfy the necessary conditions represented by these criteria are then compared on the basis of several factors that represent drilling, energy extraction and programmatic considerations.

Using this procedure, two sites have been selected for detailed consideration. These are the Long Valley caldera and coso Hot springs areas of California. The primary factors in selecting these sites are 1) the amounts of geological, geophysical and geochemical work and data that describe the two areas and 2) the potential for large shallow magma bodies at the two areas. Numerous other considerations also contributed to the selection of these sites.

In addition. two sites were selected as potential field laboratories for developing technology pieces. These are kilauea volcano. Hawaii. and Augustine volcano. Alaska. Solely in terms of the existence of shallow magma bodies, these are more attractive sites than the primary sites. However. programmatic considerations favor sites in the contiguous united states. Furthermore, the remoteness of Augustine and the National Park restrictions around Kilauea may complicate efficient long-term experimentation at either site--thus, their designation as potential field laboratories. where short-term access to magmatic environments may be gained more easily than at the primary sites. It may be advantageous to test geophysical location techniques, drilling procedures, or energy extraction systems at a field laboratory prior to use in a deep borehole. 
Finally, a few other sites were identified for continued observation. These sites, such as the Salton Trough. Medicine Lake Highlands, and the Geysers areas in California and Newberry Crater in oregon, are areas where current work is being carried out in connection with other programs. This work may result in information that makes one or more of these sites more attractive as a magma test site. In addition, unanticipated problems may arise at Long Valley or Coso Hot springs and necessitate changing the primary sites.

\section{Introduction}

Fiscal year 1984 was the first year of a U.S. Department of Energy (DOE) sponsored program to investigate the engineering feasibility of extracting energy from shallow magma bodies.[1] This project follows an extensive scientific program, sponsored by the DOE Office of Basic Energy sciences, in which the concept of reaching and extracting energy from magma was shown to be scientifically feasible--that is, there are no insurmountable technical barriers to performing each of the functions necessary for utilizing magma energy.[2] The current program will build on and expand the previous work as it provides fundamental information needed for commercial evaluation of magma energy by industry. This follow-on program is managed by sandia National. Laboratories for the Geothermal and Hydropower Technologies Division of DOE.

The long-term objective of the program is to locate a shallow magma body. drill into it, extract energy from it and study the resulting system long enough to resolve fundamental problems and determine performance parameters and system stability of the extraction process. The program essentially is an experimental program constrained by economic and feasibility evaluations. In fact. economics will continually be evaluated in order to focus research directions and determine whether the program should continue.

In order to achieve the program objectives, it will be necessary to select a single site for conducting the long-term experiment. Budget considerations and the fact that different potential magma sites can have different magma types and drilling requirements dictate that the selection of the single test site be completed early in the feasibility program. Toward this end, one goal of the first year of the program was to reduce the list of possible sites to no more than the three most promising. These will be studied and further reduced to a single site as early in the program as possible.

This report discusses the procedure that has been and will continue to be used to select potential sites. This procedure involves the following three activities: 
1. Characterizing potential magma sites. The first step in this activity is to identify those sites where the existence of shallow magma has been indicated by geological. geophysical and geochemical methods. Once a site is identified, it is characterized as well as possible using existing data. At sites that appear especially promising, field measurements will be collected to supplement existing data.

2. Identifying the site factors that are critical for success of a magma field test.

3. Evaluating the advantages and disadvantages of each site in light of the identified critical factors.

In carrying out this site selection process, several points become obvious. There is no single "best" site that is clearly superior to the others. The data that describe the sites are not complete (and never can be). and so the sites identified for serious consideration must be chosen from those that are best characterized at the current time. Finally, the site judged best for magma testing may not be the best one for commercial extraction of energy from magma. The criteria for the two uses are different. Reservoir size and longevity, ease of market access, and permitting and leasing arrangements are some of the important aspects of a commercial operation that matter little in conducting a test to investigate the engineering feasibility of the magma energy concept.

\section{II . Selection Criteria and Procedures}

Several criteria are involved in evaluating potential sites for the magma energy extraction experiment. Figure 1 illustrates the procedure undertaken to incorporate the ones judged to be most important. The figure indicates a more structured and formal procedure than is actually used, but it provides a convenient outline for discussion. The procedure for narrowing from several sites to a few, and eventually to one. involves two steps. First the many identified sites are passed through three filters that represent necessary conditions for a site to be acceptable. Following this filtering process, all sites that satisfy the three necessary conditions are compared on the basis of several secondary criteria.

Affirmative answers to the questions represented by the three filters are necessary for a site to be attractive as a test location for magma energy extraction. The questions presented below reflect scientific, institutional and logistic considerations that enter into evaluation of potential sites. 


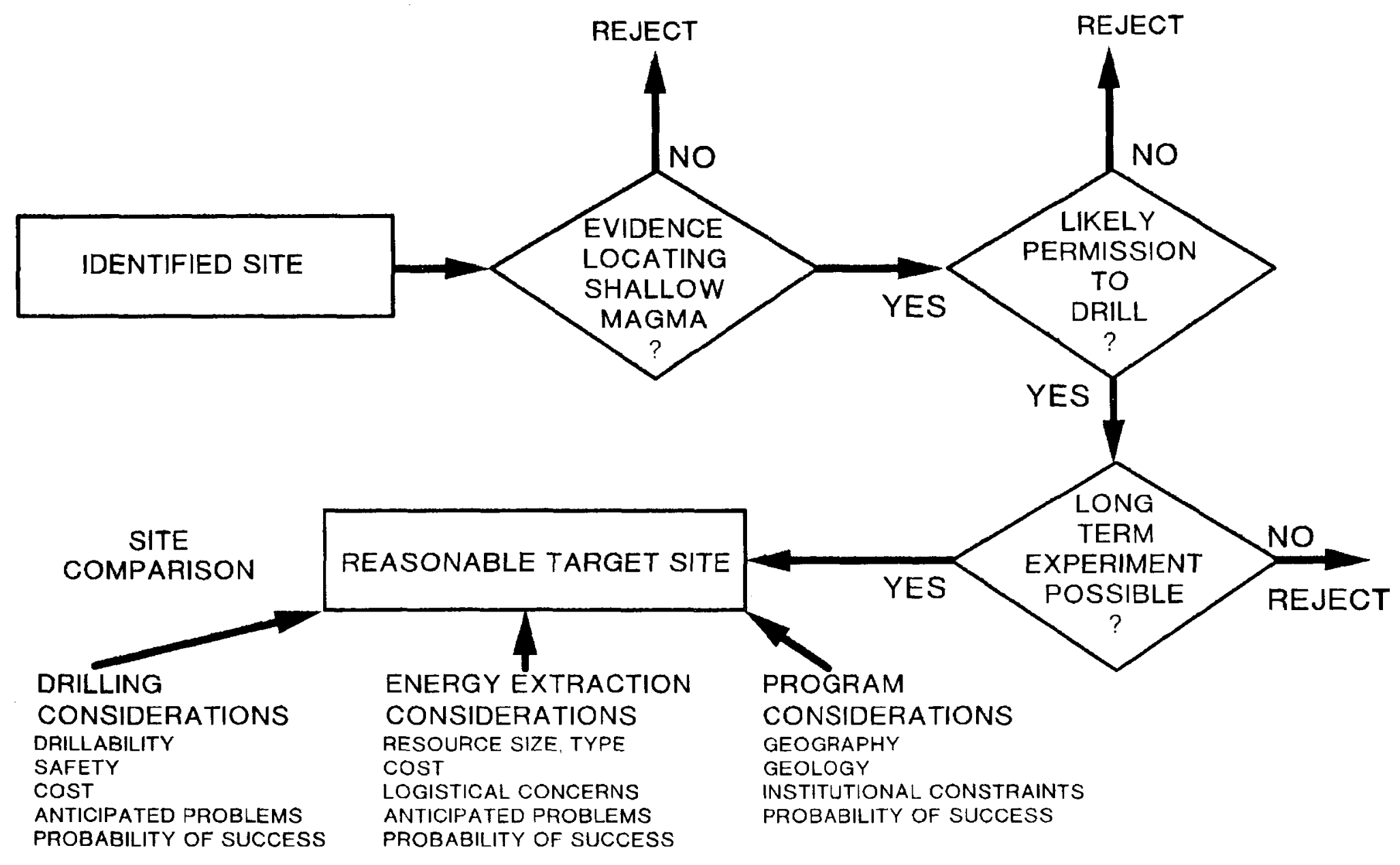

Figure 1. Representation of the site Selection Procedure 
Criterion 1 - strong evidence locating a sizeable shallow magma body This first criterion covers an area in which there is strong and divided discussion. Nearly every location at which magma is suspected has at least one informed and vocal advocate. There are four qualitative points in the statement of this criterion that need elaboration. "Strong evidence" for magma requires concurring conclusions by independent investigators as to the presence and location of a magma body. "Locating" a magma body is critical. The evidence must not only indicate that a body exists, but it must also describe its location and areal extent well enough that limited geophysical work can identify promising drilling targets. The body must be "sizfahin" from two standpoints. It must be large enough to provide a high probability of being intersected by driliing, and it must have sufficient thickness and size to assure long-term, efficient energy extraction at high power levels. One of the most important conditions for the magma body is that it be "shallow". Depth is essential to the success of defining the magma body itself and appropriate drilling targets within it, and depth also helps determine the costs for drilling to the magma. Experience with high technology oil and gas wells indicates that their total cost roughly doubles with each $1.25 \mathrm{~km}$ increase in depth. [3] and magma wells should follow the same trends. While commercial magma wells up to $7 \mathrm{~km}$ or more in depth may eventually turn out to be economic, it is esential that the early energy extraction test well(s) be as shallow as possible in order to maximize the impact of each research dollar. Informally, a target depth of $5 \mathrm{~km}$ has been selected (for an estimated related well cost of $\$ 10$ to $\$ 20$ milion).

While the parameters that describe a magma body can only be estimated. it is critical that they be estimated as accurately as possible. Recent statistics show that the success rate for wildcat petroleum wells is between $15 \%$ and 20\%. [4] Finding and drilling for magma is not nearly as well understood as searching for oil. and yet a research and development program aimed at conducting a long term extraction experiment cannot long survive with a comparable drilling success ratio. Perhaps the only way to improve the probability of success is to collect and use as much data as possible to define the target magma body.

These realities of well cost and success rate drive the consideration of magma sites toward the shallowest possible and best studied sites.

Criterion 2. The magma body can be exploited by drilling This criterion reflects institutional and logistics concerns more than technical ones. Many magma sites are located in National Parks or other protected areas. Shallow magma often occurs below unique volcanic. geyser, and fumarolic manifestations: and without a national emergency or priority. sites in protected areas are 
unlikely to be drilled, even for scientific purposes. At sites that include recently active volcanoes. topography often precludes convenient drilling: and at some. prolonged activity may constitute a safety hazard for site personnel. The remoteness of some sites. especially those outside the contiguous states, would hinder a long-term drilling operation. Application of this criterion tends to favor sites at which drilling, especially for geothermal resources, has already been done. At such sites the institutional. logistical, and environmental constraints have been defined and at least partially satisfied during the previous drilling effort.

Criterion 3. A long-term energy extraction experiment can be conducted

This criterion is primarily logistical. The purpose of the planned experiment is engineering evaluation of the energy extraction system over an extended period of operation. Sites with severe climates or no convenient road access would make long-term, continuous operation difficult at best. The program will be budget limited and so the logistics system required to support the experiment must be reasonable. This criterion argues against remote and extreme weather sites.

The Comparison Phase

The best site or sites for a magma experiment must be chosen from those that survive the filtering process. As indicated in Figure 1. the sites that meet all three requirements are subsequently compared using three types of factors--those related to drilling. those related to energy extraction and those arising from programmatic concerns. The first two types of factors are similar. Examples include anticipated cost, potential problems, expected probability of success, and safety considerations. The programrelated areas are more qualitative. including such concerns as whether the site is geologically or geographically representative of other sites, whether permitting problems can be anticipated, and whether a site might elicit more or less interest by industry. The technical issues that affect cost and probability of success are of greatest importance; but in comparing sites where these cannot be distinguished, the program considerations can be used to differentiate.

IV. Potential Magma Experiment sites

There are numerous potential sites for conducting a magma energy extraction experiment. The ones considered in detail are shown in Table 1. This list comes from Hardee's analysis of the most likely sites for shallow magma bodies.[5] Detailed discussion of the characteristics of the various sites can be found in Hardee's paper.

Several studies have characterized potential magma bodies. and many are referenced by Hardee. In addition, a large portion of the first year effort in the magma program was directed toward site characterization. This included a study of the data describing 
Table 1. Potential Magma Sites (From Hardee [5])

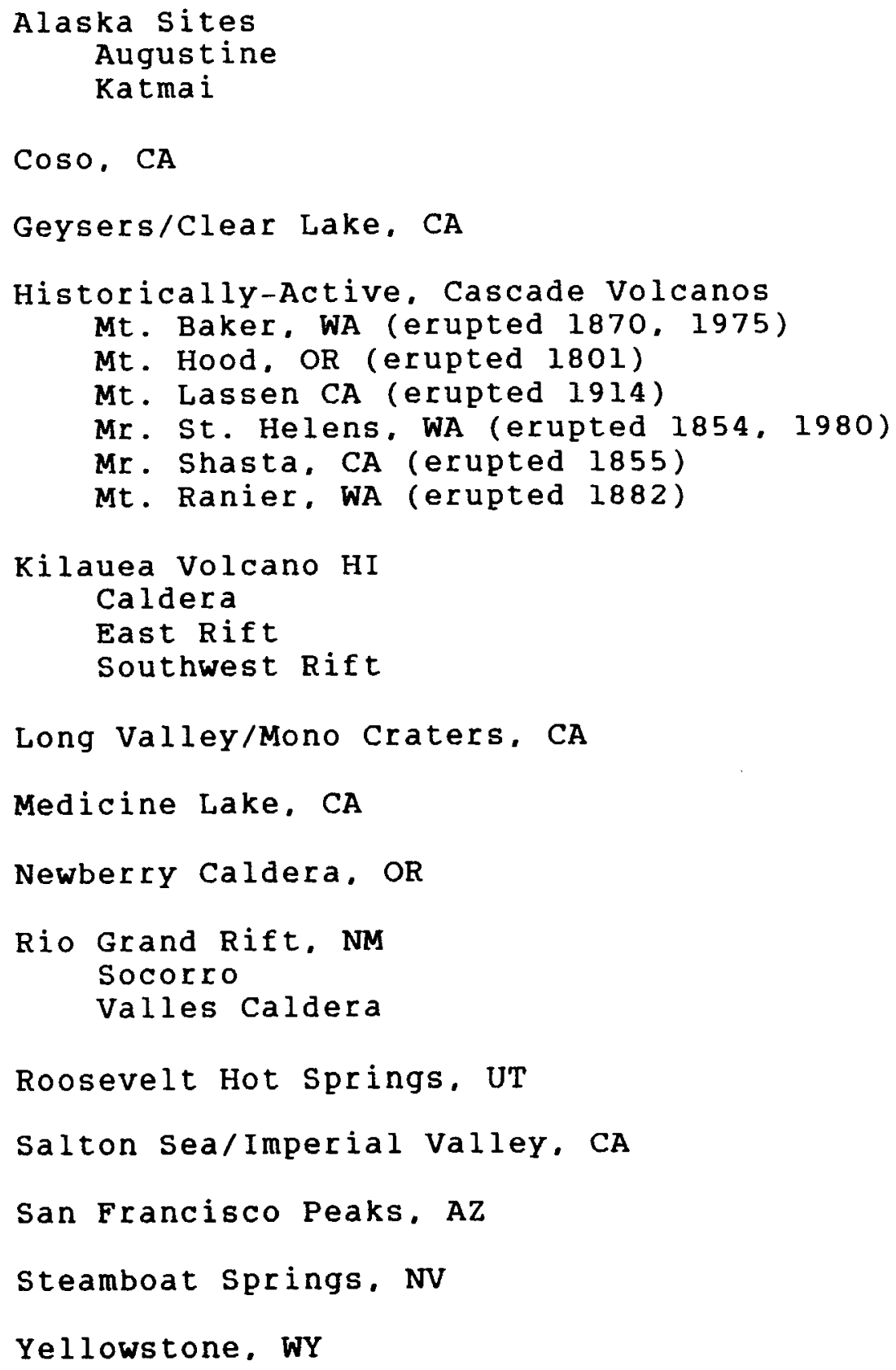


five promising california sites [6], an analysis of the institutional factors related to all the sites listed in Table 1 [7], and study of the anticipated drilling costs of the most promising sites [8]. Visits were made to several locations to view and discuss the sites with involved investigators, and geological and geochemical surveys were made at several of the most promising sites. Results and conclusions from all of these efforts are summarized by Hardee [5] and were included in the site evaluations and site selection process.

It is impossible to include all potential magma sites on a single list. Those in Table 1 comprise a conservative listing of sites for which a minimal set of data is currently available to describe suspected magma bodies. Other sites will join the list as more is learned about them, and undoubtedly. some sites will be dropped from the list. The magma energy extraction program will follow the data collection processes at the various sites in order to include the latest and best information in decisions. However. budget realities necessitate limiting the sites under consideration to those that have the best current data.

V. $\quad$ Results

The selection of a best site for a magma energy experiment is difficult and quite subjective. The procedure outlined above attempts to minimize subjectivity, but the process cannot be completely mechanized. The Appendix presents a brief site-by-site discussion of the factors that most heavily influenced the decision to include sites for further consideration or to eliminate them. As has been discussed, the most important features for consideration were the quantity of currently existing data that locate magma at a site and the estimated depth to a magma chamber.

The fiscal year 1984 goal was to select the three best sites for the magma energy extraction experiment. However, the selection procedure did not result in three sites that were clearly superior to the others. Instead, three groups of sites were identified for further consideration in different ways.

\section{Primary sites}

Two California sites, Long Valley and the general coso Hot springs area, emerged from the selection process as the most promising sites for conducting a magma energy extraction experiment. These are among the most studied magma regions in the country, and both offer good chances for finding sizeable shallow magma bodies. The case for the presence of an acceptable shallow body at Long Valley is currently stronger than the case for coso Hot springs. and detailed geophysical work (primarily seismic) will be used to better define the (possible) magma chambers in both areas. Future site characterization work will be directed towards selecting one of these primary sites as the preferred site for a magma energy experiment. 
The individual factors that led to the selection of these as primary sites are discussed in the Appendix, but one shared factor deserves discussion. These two areas are quite similar--both geologically and geochemically. This strengthens the arguments for each, as it allows a common technology development effort rather than separate ones. As a result, the pressure to choose between the sites prematurely is reduced.

Another factor that is especially important for Long Valley is the possibility for synergism among the site studies done for the magma program and those done by the DOE office of Basic Energy sciences for the Continental scientific Drilling Program and those done by the U.S. Geological survey for volcanic hazard studies.

\section{Field Laboratories sites}

Two active volcanoes have been identified that provide relatively easy access to high temperature and magmatic environments. Though each of these sites. Kilauea. Hawaii. and Augustine, Alaska. has features that would cause difficulty for a long term experiment, they provide relatively shallow, certain access to magma for testing components and concepts on a scale that is impossible in a scientific laboratory. For this reason, they have been identified as potential field laboratories. One disadvantage of both sites that prevented their being designated as "primary sites" is that they are not "continental" sites, and an objective of the program is to demonstrate the feasibility of magma as a continental energy resource. In addition, Kilauea introduces the institutional and environmental problems of conducting a long term experiment in or very near a National Park, while the problems at Augustine would be the logistics problems of severe weather and long supply lines for conducting a long-term extraction experiment. Furthermore. Kilauea, with basaltic magma, and Augustine, with andesitic magma, are not representative most continental magma sites.

\section{other sites}

other of the potential magma sites listed in Table 1 are being studied for different purposes by other programs, and the magma energy program must maintain close contact with these efforts and utilize the results. The necessity to continue evaluating other sites comes from three considerations: 1. Shallow magma may be found at one or more of the sites: 2. It is possible that technical. institutional or other problems could make the identified primary sites unavailable or unattractive for the long term experiment and an alternative site might become necessary: and 3 . During the evaluation of the feasbility of magma energy extraction. it will be necessary to assess the realistic resource potential, and estimates for each site must be based on the most current information. sites that must be watched include the salton Trough area which will be the site of a research hole drilled by DOE. the Inyo Domes (Long Valley) and Valles Caldera areas that are being drilled by the Continental scientific Drilling Program, the Cascades and other 
areas that are the subject of detailed geothermal resource evaluations, and areas underlying geothermal fields, such as the Geysers. where private exploration activity is conducted.

Two other potentially very attracive areas will be closely observed. These two sites, Medicine Lake, California, and Newberry Caldera, oregon, are so similar to each other as to be termed geologic "twins". They display some of the most recent igneous formations in the U.S. and have the potential for having very shallow magma chambers $(3-5 \mathrm{Km})$. They have not been as thoroughly studied as Long Valley, Coso Hot springs or many of the other sites and as a result, they cannot be considered as primary sites. However, the importance of the depth of the magma to the probability of success and overall cost of the experiments is so great, that these sites with potential for very shallow magma cannot be dismissed at the current time. 


\section{References}

1. "Multi-Year Program Plan, Magma Energy Extraction," DOE/GHTD, February, 1984 .

2. Colp. John L., "Final Report - Magma Energy Research Project," SAND 82-2377. Sandia National Laboratories. October, 1982.

3. "1982 Joint Association Survey on Drilling Costs." American Petroleum Institute, November. 1983.

4. Johnston, Robert R., "North American Drilling Activity in 1982." The American Association of Petroleum Geologists Bulletin, V-67. No. 10, October, 1983.

5. Hardee, H. C.. "Shallow Magma Targets in the Western U.S., "SAND 83-1361, Sandia National Laboratories, October, 1984.

6. Goldstein, N. E. and S. Flexser, "Melt Zones Beneath Five Volcanic Complexes in California: An Assessment of Shallow Magma Occurrences," LBL-18232, Lawrence Berkeley Laboratory. August. 1984 .

7. Blackett, R., and H. Lee, "Preliminary Comparison of Physical and Institutional Factors Affecting a site selection Among 21 Potential Magma Energy Study Areas." MCD 84-012-TM. Meridian Corporation, August, 1984 .

8. Well Production Testing, Inc., Report to be Published, Sandia Contract 58-1458. 
Appendix. Discussion of Important Characteristics of

\section{Individual sites}

The characteristics of the potential sites for the magma energy extraction experiment were summarized by Hardee [5], and the ranking here is similar to the preliminary ranking from that work. An effort is made here to identify the major factor or factors that led to the indicated classification for each site.

\section{Primary Sites}

Two sites have been identified as primary sites for consideration for the extraction experiment. These sites will be studied and compared in order to determine the best site for conducting the experiment.

1. Long Valley, California -. Extensive scientific investigations have been carried out to map the magma chamber(s) underlying the Long valley area, and two shallow tops $(\leq 5 \mathrm{~km})$ to the chambers have been identified. The size of the chamber and likely nature of the magma seem appropriate for a long term experiment. The only disadvantage may be confusing environmental, political and institutional factors, although geothermal drilling and development are proceeding in the area. The factors that led to the high regard for the Long Valley area are the large quantities of data that have been collected about the underlying magma chamber and the number of continuing and planned investigations into its characteristics.

2. Coso Hot springs, California -- This area has also been heavily studied, but less work has been done here than at Long valley. Furthermore, the work that has been done is less definitive. The magma appears to be deeper at coso than at Long Valley. but a recent investigation has indicated a possible shallow chamber to the south. The institutional and logistics problems would likely be less at Coso, and geothermal development is proceeding. The major question mark remaining is the actual depth to the magma chamber. The major factors favoring the general coso Hot springs area are the quantity of data that indicate the location of $a$ shallow magma body $(6-8 \mathrm{Km})$ and the single landowner (the U.S. Navy) that could be a cooperative partner in a magma energy experiment.

\section{Field Laboratory sites}

Two sites, which could provide access to shallow magma but which are not "continental" sites, are identified as potential field laboratory sites.

1. Kilauea, Hawaii -. The potential for finding very shallow magma (1-3 $\mathrm{Km})$ beneath private land at the upper east rift zone looks quite good. Local opposition to geothermal drilling has been 
strong. but a magma test well might see less opposition. The major disadvantages are that the site is in close proximity to a National Park, the magma is basalt, unlike most continental sites, and the magma away from the main caldera occurs as thin dike or tube intrusions.

2. Augustine, Alaska - - This volcano has been studied fairly extensively and strong evidence indicates the presence of a shallow magma chamber 1 to $3 \mathrm{~km}$ beneath the summit. Topography around the cone would complicate drilling but not make it impossible. The major disadvantage for Augustine is the difficult logistics for conducting a long-term, year-round extraction experiment.

\section{other sites}

There are numerous other potential magma sites, but none has been studied as well as the primary sites. The first five listed below are the most attractive. but each has a major factor that keeps it from further consideration. These include suspected magma body size,magma chamber depth and limited geophysical data.

1. Salton Trough, California - The geothermal anomalies in this area appear to be driven by a shallow magmatic source. The area has been extensively studied and will continue to be the object of numerous investigations. The major factor that prevents this from being a "primary" site is the feeling that the shallow occurrences of magma are small intrusions (dikes and sills) through highly faulted and fractured spreading centers. The commercial and scientific drilling and exploration occurring in the salton Trough area may result in changes to this model of the underlying magma. and this could cause a change in designation to primary site.

2. Geysers/Clear Lake, California - This area has been studied as extensively as the primary sites, and the presence of a magma body is strongly indicated. Furthermore, geothermal drilling has a long history in the area, and permitting and environmental problems would not likely be difficult. However, several investigators have shown the magma chamber to be at more than $10 \mathrm{Km}$ depth. Such a depth is not suitable for the first energy extraction experiment, and so continuing study is warranted.

3. Medicine Lake, California -- This site has very strong geological evidence for a sizeable shallow magma body. However. geophysical evidence is fairly weak due to lack of data. Geothermal drilling is planned for the area, but there is no indication of whether institutional problems would slow magma drilling. The site is relatively remote, and winter snows are severe. The major attraction of Medicine Lake is the lure of potentially very shallow magma (3-5 Km).

4. Newberry Crater, Oregon - This site is quite similar to Medicine Lake, but it has been studied a little more. It too offers the potential for very shallow magma and high temperatures 
at shallow depths. based on strong geologic evidence, but it may have more stringent institutional and political constraints. Geothermal drilling is planned for the flanks of the crater, but none is permitted in the caldera itself.

5. Socorro, New Mexico -- This site has not been studied as extensively as many other sites. The presence of a deep (15-20 $\mathrm{Km})$ magma body is strongly indicated, but only limited work has shown the existence of several suspected shallow bodies $(4-7 \mathrm{Km})$ over the deeper one. The logistics for this site would not be a problem, and institutional and environmental constraints could probably be satisfied. The major drawback is the lack of supporting data for the indications of shallow chambers. Although in many ways this is the most attractive site in this category, an extensive survey effort would be needed to make socorro a "primary" site.

6. Other Geothermal Sites - Several other geothermal sites have been mentioned as potential magma experiment sites. and undoubtedly many will eventually prove to have reachable, sizeable magma chambers underlying them. However, at this point none has been studied well enough to warrant further consideration. The results of geophysical and other surveys will be observed in order to consider these sites when it is appropriate.

7. Mount St. Helens and other Volcanoes -.. The volcanoes at Mount St. Helens, Katmai, and other sites do provide potential shallow magma targets. At Mount $s t$. Helens, for example, data indicate the presence of a magma chamber 2 to $3 \mathrm{~km}$ below the summit. However. this and the similar sites have three major drawbacks. They generally occur in protected areas which preclude drilling --Mount St. Helens has been declared a National Geological Monument and Katmai is a National Park: they often are in remote. severe weather areas where year-round continuous access is difficult and where topography complicates drilling: and they can present safety problems for activities requiring long-term exposure.

8. Yellowstone, Wyoming -- scientifically, this may be the most attractive site of all. However, the institutional and political problems associated with the National Park preclude any consideration as long as other sites might be available.

9. Valles Caldera, New Mexico -.. This site is attractive from many standpoints. However, the major drawback is a lack of agreement on or data defining the location of a shallow magma body. Suspected depth to the magma body is too great to justify further consideration. 
DISTRIBUTION :

TID-4500-R66-UC-66C (507)

A. Aducci

U.S. Department of Energy

San Francisco Operations office

1333 Broadway

Oakland, CA 94612

Jim Albright

Los Alamos National Labs

Mail Stop 676

Los Alamos, NM 87545

David N. Anderson

Geothermal Resources Council

P.O. Box 1350

Davis, CA 95617

Dr. Carl Austin

Code 266

Geothermal Utilization Div.

Naval Weapons Center

China Lake, Calif. 93555

Wm. Christopher Allen

Union oil Co. of California

Research Department

P.O. Box 76

Brea, CA 92621

Gudmundur Bodvarsson

Lawrence Berkeley Laboratories

B90-1106

Berkeley. CA 94720

John L. Colp. Vice President

Island Science, Inc.

1023 Washington SE

Albuquerque, NM 87108

Bob Decker

Branch of Field Geochemistry and

Petrology

U.S. Geological survey

345 Middlefield Rd.

Menlo Park, Ca 94025

Tom Doe

Lawrence Berkeley Laboratories

B50A- 1140

One Cyclotron Rd.

Berkeley, CA 94720

Wilfred Elders

IGPP

Univ. of Calif.

Riverside, CA 92521

Mel Friedman

Center for Tectonophysics and

Dept. of Geology

Texas A\&M University

College Station, $\mathrm{TX} 77843$

Frazer Goff

Los Alamos National Labs

Mail stop

Los Alamos, NM 87545

Dr. Norm Goldstein

Lawrence Berkeley Laboratory

1 Cyclotran Rd.

Berkeley. CA 94720

Joseph L. Iovenitti

Diamond Shamrock Thermal Power Co 333 Mendocino Ave, Suite 120

Santa Rosa, CA 95401

L. J. Patrick Muffler

Branch of Field Geochemistry and Petrology

U.S. Geological Survey

345 Middlefield Rd.

Menlo Park, CA 94025

James L. Moore

Vice President Exploration

California Energy Co.

3333 Mendocino Ave.

Santa Rose. CA 95401

Tom Henyey

Dept. of Geological Sciences

University of Southern California

Los Angeles, CA 90007

John F. Hermance

Department of Geological Sciences Brown University

Providence, RI 02912 
H. Mahadeva Iyer

U.S. Geological Survey

345 Middlefield Rd.. MS 77

Menlo Park, CA 94025

Paul Kasameyer

Lawrence Livermore Laboratories

P.O. Box 808

Livermore, CA 94550

Steve Knabe

Pennzoil

Box 2967

Houston, TX 77252-2967

George A. Kolstad

U.S. Department of Energy

Office of Basic Energy Sciences

Mail stop J-309

Washington. D.C. 20585

James Moore

U.S. Geological Survey

345 Middlefield Road

Menlo Park. CA 94025

Marshall J. Reed

U.S. Department of Energy

Geothemal Hydropower

Technologies Division

Forrestal Bldg.. CE 324

1000 Independence Ave. S.W.

Washington. D.C. 20585

James V. Satrape

5113 Leesburg Pike, suite 700

Falls Church, VA 22041

Dennis T. Trexler

Division of Earth Sciences, UNLV 255 Bell St.. Suite 200

Reno, Nevada 89503

Lee Younker

Lawrence Livermore Laboratories

P.O. Box 808

Mail Code L-209

Livermore, CA 94550
Public Works Dept.

Geothermal Utilization Division

Naval Weapons Center

China Lake, CA 93555

Attn: Dr. Carl Austin

Comm. D. Stevens

Mike M. Wright

Earth science Laboratory

Univ. of Utah Research Inst.

391 Chipeta Way, Ste A

Salt Lake City, UT 84108

U.S. Department of Energy (3)

Geothermal Hydropower

Technologies Division

Forrestal Bldg., CE 324

1000 Independence Ave. S.W.

Washington, D.C. 20585

Attn: J. Bressee

M. Reed

R. Toms

W. P. Grace, DOE/AL

Nuclear \& Geosciences Division

1540 W. C. Luth

1541 H. C. Hardee

1541 J. B. Rundle

1543 T. M. Gerlach

1543 J. C. Eichelberger

3141 L. J. Erickson (5)

3151 W. L. Garner

6200 V. L. Dugan

6240 R. K. Traeger

$6240 A$ P. C. Lysne

6241 J. R. Kelsey

6241 C. C. Carson (5)

$6241 \mathrm{~J} . \mathrm{T}$. Finger

6242 J. C. Dunn (25)

6242 T. Y. Chu

6242 C. B. Hickox

6242 R. D. Jacobson

6250 B. W. Marshall

8024 M. A. Pound 